\title{
The Strength and Density of Green and Reduced Briquettes Made with Iron Ore and Charcoal
}

\author{
Michael A. Somerville ${ }^{1}$
}

Published online: 5 May 2016

(C) The Minerals, Metals \& Materials Society (TMS) 2016

\begin{abstract}
Composite briquettes or pellets consisting of iron ore, carbon, and a binder are a source of direct reduced iron (DRI). In the handling of green and reduced briquettes, high strength is important to minimize briquette breakdown. The use of charcoal as a source of carbon, rather than coal provides a way of introducing renewable carbon into the ironmaking process. Composite briquettes were made with Australian hematite iron ore, low volatile charcoal and $2 \%$ starch as a binder. The carbon-to-iron mass ratio was varied between 0.18 and 0.26 . The green briquettes were heated to either 1300 or $1350{ }^{\circ} \mathrm{C}$ for times varying from 3 to $15 \mathrm{~min}$. After heating, the briquettes were tested for compressive strength, density, and the degree of iron metallization. The aim of the work was to determine the key strength forming features of the briquettes during heating and reduction. Dried green briquettes, made with a starch binder, were found to be very strong and required a force of at least $3800 \mathrm{~N}$ to yield under compression. After heating for $3 \mathrm{~min}$, the briquettes lost strength rapidly before regaining strength at longer heating times of 10 and $15 \mathrm{~min}$. Increasing the $\mathrm{C} / \mathrm{Fe}$ ratio in the briquette mix decreased the strength and density, and increased the iron metallization of the heated briquettes. Briquette strength also increased with increasing time from 10 to $15 \mathrm{~min}$ and heating temperature from 1300 to $1350{ }^{\circ} \mathrm{C}$. These observations can be explained in terms of the distance between iron oxide particles in the briquette
\end{abstract}

The contributing editor for this article was Sharif Jahanshahi.

Michael A. Somerville

michael.somerville@csiro.au

1 CSIRO Mineral Resources, Private Bag 10, Clayton South, VIC 3169, Australia mix. At low $\mathrm{C} / \mathrm{Fe}$ ratios, iron oxide particles will be relatively close together which facilitates the development of a connected slag network which acts as a binder and increases briquette strength.

Keywords Composite briquette - Charcoal · DRI · Compressive strength $\cdot$ Slag $\cdot$ Iron metallization · Density

\section{Introduction}

Composite briquettes are solid mixtures of iron ore and carbon often with a binder and flux additive. When heated, the iron oxides are reduced through a series of gas-solid reactions. The resulting sponge or direct reduced iron (DRI) can be used as a supplementary iron source to a blast furnace or as a feed material to an electric arc furnace [1]. Composite pellets or briquettes also find use as the feed material for new generation iron-making technology such as Fastmet [2, 3] or ITmk3 [4], which uses a rotary hearth furnace-based process. These processes have been developed in order to make iron without requiring expensive coke as needed in blast furnace iron-making and also to improve process flexibility such as improved down-turn in production rate.

Much work has been performed on the preparation and characteristics of composite briquettes or pellets made from iron ore and coal. Less work has been directed to the properties of green and heated composites using charcoal as the carbon source. The use of charcoal in composite briquettes, sourced from sustainable biomass resources, could be a convenient way of introducing renewable carbon into the iron-making process. Charcoal has a lower ash content than coal and the ash is normally less acidic, i.e., it has a relatively high $\mathrm{CaO} / \mathrm{SiO}_{2}$ ratio [5]. 
Jahanshahi et al. [6] and Mathieson et al. [7] have estimated the amount of net $\mathrm{CO}_{2}$ emissions which could be saved if charcoal were substituted for coal in various ironand steel-making operations. These savings range from 0.41 to $0.55 \mathrm{t}-\mathrm{CO}_{2} / \mathrm{t}$-crude steel for the blast furnace tuyere injection where charcoal replaced $100 \%$ of the presently injected coal to savings of only $0.02-0.11 \mathrm{t}-\mathrm{CO}_{2} / \mathrm{t}$-crude steel for charcoal added to the coke making blend at 2-10\% replacement levels. Mathieson [7] assumed that unreduced iron ore/charcoal composites could replace $5-10 \%$ of the iron charge to a blast furnace. At this level of replacement, the net $\mathrm{CO}_{2}$ emissions would be reduced by $0.08-0.15 \mathrm{t}-\mathrm{CO}_{2} / \mathrm{t}$-crude steel which represents $3-7 \%$ of the total $\mathrm{CO}_{2}$ emissions from iron making, assuming that the carbon was sourced from sustainable biomass resources.

Many studies have been conducted on the reduction kinetics of composite briquettes/pellets, and the key factors affecting the rate of iron reduction have been determined. Ghosh [8] summarized the work of many researchers and concluded that the reduction of iron oxides by carbon occurs via a two-step process, with the steps occurring in parallel: The gasification of carbon (Eq. 1) and the reduction of iron oxides by the generated CO gas [Eqs. (2), (3), and (4)]. The overall reaction is controlled by the rate of carbon gasification. As the rate of carbon gasification increases, through the effect of catalysts or use of more reactive carbon sources, the rate of oxide reduction can start to influence the overall rate.

$\mathrm{C}+\mathrm{CO}_{2}=2 \mathrm{CO}$

$3 \mathrm{Fe}_{2} \mathrm{O}_{3}+\mathrm{CO}=2 \mathrm{Fe}_{3} \mathrm{O}_{4}+\mathrm{CO}_{2}$

$\mathrm{Fe}_{3} \mathrm{O}_{4}+\mathrm{CO}=3 \mathrm{FeO}+\mathrm{CO}_{2}$

$\mathrm{FeO}+\mathrm{CO}=\mathrm{Fe}+\mathrm{CO}_{2}$

The overall reaction is a combination of Eqs. (5) and (6). Equation (5) indicates that stoichiometric reduction of hematite would require a $\mathrm{C} / \mathrm{Fe}$ mass ratio of 0.161 . However, at typical reaction temperatures and with some available carbon to react with $\mathrm{CO}_{2}$ via Eq. (1), Eq. (6) may occur, implying a $\mathrm{C} / \mathrm{Fe}$ ratio of 0.323 . In practice, $\mathrm{C} / \mathrm{Fe}$ ratios of 0.25 or more are required to achieve high degrees of iron metallization, implying a combination of Eqs. (5) and (6).

$2 \mathrm{Fe}_{2} \mathrm{O}_{3}+3 \mathrm{C}=4 \mathrm{Fe}+3 \mathrm{CO}_{2}$

$\mathrm{Fe}_{2} \mathrm{O}_{3}+3 \mathrm{C}=2 \mathrm{Fe}+3 \mathrm{CO}$

In processes involving the reduction of a bed of composite briquettes/pellets, heating occurs in a non-isothermal system as some of the pellets will be shielded by material closer to the heat source. Many workers [9-14] have studied the reduction kinetics of this situation and concluded that heat transfer through a bed could limit the overall reduction rate. Sharma [13] showed that temperature had the strongest effect on reduction followed by time and $\mathrm{C} / \mathrm{Fe}$ mass ratio.

Dutta and Sah [15] investigated the reduction of coaliron composite pellets. They conducted smelting/reduction experiments by immersing composite pellets in a liquid iron bath at $1450{ }^{\circ} \mathrm{C}$. The effect of $\mathrm{C} / \mathrm{Fe}$ ratio in the pellets and immersion time on the degree of reduction was determined. Three stages of reduction were observed: The first stage was a relatively slow incubation stage while the pellets are heated. The second stage was relatively fast due to the release of volatile matter from the pellets. In the final stage, sintering and densification of the product DRI decrease the diffusion rate of $\mathrm{CO}$ and $\mathrm{H}_{2}$ and hence restrict the reduction rate before the pellet melts. The degree of reduction of the pellets increased with an increase in the $\mathrm{C} / \mathrm{Fe}$ ratio of the pellets.

Fortini and Fruehan [16] and Halder and Fruehan [17] reported on the reduction of composite pellets made with charcoal. They showed that the reduction rate of composite pellets made with charcoal is higher than that of comparable pellets made using coal. The higher rate was attributed to higher reactivity of charcoal with $\mathrm{CO}_{2}$ and in turn to higher internal pore surface area.

A number of problems have been reported when charcoal is used in composite briquette and pellets. During investigations into the reduction of composite pellets containing charcoal, coke, and coal, Gupta and Misra [18] found that charcoal resulted in higher iron reduction rates and higher extent of reaction, but the composite pellets tended to fall apart during heating due to the formation of iron whiskers within the DRI matrix.

Work has also been performed on the formation of composite briquettes/pellets made with coal and a range of binders used to impart cold strength. These binders include thermosetting resins [19], dextrin [20, 21], molasses, sodium silicate, bentonite and starch [22], sponge iron fines, lime and dextrose [23], Portland cement [24, 25], alumina cement [26], and calcium aluminate [27]. The general understanding is that the principal strengthening mechanism of heated briquettes involves the formation of interconnecting slag and metallic phases. Slag phases can form from the combination of inorganic components in coal or char ash, binders, and gangue from the ore. Metallic phases can also form strength forming networks at high levels of pellet reduction/metallization. In this work, starch was used as a binder. Preliminary work showed that starch, activated with a small amount of moisture, produced very strong green briquettes after drying.

Longbottom et al. [28, 29] showed that the strength of reduced coal/ironsand compacts was due to the formation of a slag phase which forms from the mineral matter of the 
coal and gangue components of the iron ore. This slag first coated the reducing iron oxide and sponge iron particles. Slag from different particles then combined to form a slag network between the iron oxide particles. Processing parameters, such as increasing temperature and the addition of fluxes which increased slag formation, were found to greatly increase the strength of the reduced compacts. Decreasing the distance between iron oxide particles by increasing iron-to-carbon ratio in the compact mix or decreasing the particle size was also found to increase the strength of the compacts after heating.

The aim of the current work was to examine the structural features of heated composite briquettes made with iron ore and charcoal and determine which features imparted strength to the reduced briquette. This paper presents work on the effect of heating time and carbon-toiron mass ratio $(\mathrm{C} / \mathrm{Fe})$ in the briquette mix on the strength, density, and iron metallization of fired briquettes.

\section{Experimental}

The composite briquettes were made using an Australian hematite iron ore, charcoal made from the pyrolysis of a Eucalypt hardwood at $800{ }^{\circ} \mathrm{C}$, with $2 \%$ starch as a binder. Twenty percent additional moisture was added to the briquette mix to provide optimal strength. Table 1 shows the composition of the iron ore, and Table 2 shows the proximate and ultimate analysis of the charcoal (ISO standard). The charcoal samples were pulverized in a ring mill for about $10 \mathrm{~s}$ to ensure a well-mixed and very fine starting material. The iron ore was crushed in a rolls mill to ensure the lumps were eliminated but otherwise was used as received. Table 3 shows the size range of the different materials as measured by a Malvern Mastersizer. Ethanol was used the dispersant for the iron ore and water for the charcoal. The $\mathrm{D}_{10}, \mathrm{D}_{50}$, and $\mathrm{D}_{90}$ results refer to the size $(\mu \mathrm{m})$ at which 10,50 , and $90 \%$ of the material, respectively, would pass.

Differing amounts of charcoal and iron ore in the briquette mix established the target $\mathrm{C} / \mathrm{Fe}$ ratios $(0.18-0.26)$. Green briquettes were prepared by pressing about $30 \mathrm{~g}$ of the briquette mixture in a $25-\mathrm{mm}$ die and plunger at $5 \mathrm{MPa}$ pressure. Previous preliminary work established that a mixture pressed at this pressure produced strong green briquettes after drying at $105^{\circ} \mathrm{C}$. Cylindrical briquettes of diameter $25 \mathrm{~mm}$ and with an aspect ratio close to 1 were
Table 2 Proximate and ultimate analysis of the charcoal used to make the composite briquette (wt $\%, \mathrm{db})$

\begin{tabular}{lllllllll}
\hline Ash & VM & FC & C & H & N & S & Cl & O \\
\hline 3.5 & 2.1 & 94.5 & 92.2 & 0.8 & 0.25 & 0.03 & 0.02 & 3.2 \\
\hline
\end{tabular}

$V M$ volatile matter, $F C$ fixed carbon i.e.100-ash-VM, $O$ 100-ash-C-H$\mathrm{N}-\mathrm{S}-\mathrm{Cl}, d b$ dry basis

Table 3 Size range of iron ore and charcoal $(\mu \mathrm{m})$

\begin{tabular}{llll}
\hline Material & $\mathrm{D}_{10}$ & $\mathrm{D}_{50}$ & $\mathrm{D}_{90}$ \\
\hline Charcoal & 2.7 & 9.3 & 380 \\
Iron ore & 0.48 & 5.8 & 21.0 \\
\hline
\end{tabular}

produced. These briquettes were prepared without additional fluxes.

After drying, the briquettes were heated at either 1300 or $1350{ }^{\circ} \mathrm{C}$, for times varying between 3 and $25 \mathrm{~min}$, in a sealed vertical tube furnace under a flowing argon stream. Figure 1 shows a schematic of the experimental arrangement. A platinum wire and cradle arrangement was used to hold and lower a single green briquette to the central constant temperature region of the tube furnace for the predetermined time. The wire was clamped to the top endcap to allow a secure hold of the position of the briquette and also to allow the briquette to be moved within the furnace tube. A thermocouple clamped to the bottom end cap measured the temperature just below the briquette when it was located in the center of the furnace tube. After heating, the briquette was raised to a cool region at the top of the tube where it was allowed to cool under flowing argon.

The cooled briquette was removed from the furnace and stored in a moisture and oxygen-free environment prior to determination of longitudinal compressive strength, density, and degree of iron metallization. Selected briquette samples were also examined by scanning electron microscopy (SEM) and individual phases were analyzed by X-ray energy dispersive spectroscopy (EDS). Compressive strength was measured using a Tinius Olsen single column universal tester where the briquette strength was taken as the force $(\mathrm{N})$ required for the briquette to yield. Density was calculated from the dimensions and mass of the briquettes after heating.

The metallic iron content of heated briquettes was determined by bromine/methanol extraction of the metallic component. The digested sample was filtered and the
Table 1 Composition of the iron ore used to make the composite briquettes (wt\%)

\begin{tabular}{llllllllll}
\hline $\mathrm{Fe}$ & $\mathrm{SiO}_{2}$ & $\mathrm{CaO}$ & $\mathrm{Mn}$ & $\mathrm{Al}_{2} \mathrm{O}_{3}$ & $\mathrm{P}$ & $\mathrm{S}$ & $\mathrm{K}_{2} \mathrm{O}$ & $\mathrm{Na}_{2} \mathrm{O}$ & LOI \\
\hline 61.6 & 4.3 & 0.26 & 0.34 & 2.25 & 0.058 & 0.013 & 0.038 & 0.11 & 2.71 \\
\hline
\end{tabular}

LOI loss on ignition at $900{ }^{\circ} \mathrm{C}$ 


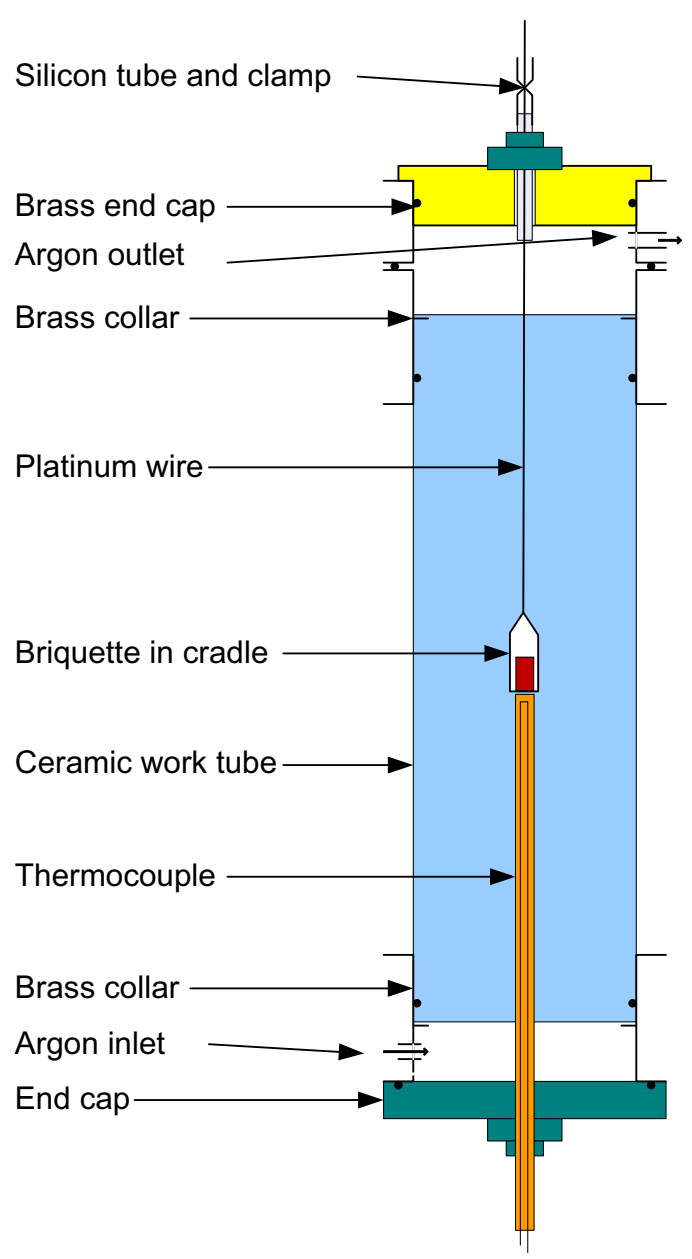

Fig. 1 Schematic diagram of the apparatus used to heat the green composite briquettes (Color figure online)

filtrate was analyzed for iron using standard ICP techniques. The total iron content of the briquettes was determined by x-ray fluorescence (XRF) analysis of fused glass disks. The level of iron metallization was the percentage of the total iron present in metallic form.

Four series of briquettes were produced and are distinguished by their carbon-to-iron ratio in the briquette mix $(\mathrm{C} / \mathrm{Fe})$, firing temperature, and the time at which the briquettes were at the experimental temperature, i.e., heating time. The conditions used in the four series are shown in
Table 4. The $\mathrm{C} / \mathrm{Fe}$ mass ratio was calculated from the analyses shown in Tables 1 and 2, using FC as an appropriate and conventional approximation for carbon content. The $\mathrm{C} / \mathrm{O}$ mole ratios were calculated from the fixed carbon content of the charcoal and the oxygen content of the iron ore associated with iron, assuming that iron was present as hematite.

\section{Results and Discussion}

The heated briquettes in this work generally all had strength greater than $500 \mathrm{~N}$. Phenomena observed in other work on composite briquettes made with charcoal, which decreased strength after heating, such as the formation of iron whiskers were not observed in this work. The strength was related solely to the briquette microstructure.

\section{Effect of Heating Time}

Figure 2 shows the effect of briquette heating time at $1300{ }^{\circ} \mathrm{C}$ on the strength and density of briquettes (Series 1). The initial green briquettes (zero heating time) were very strong and possessed compressive strength of about $3.8 \mathrm{kN}$. After heating for even a short time $(3 \mathrm{~min})$, the strength decreased rapidly to about $200 \mathrm{~N}$ as the starch binder was destroyed. The strength increased at longer heating times of 10 and $15 \mathrm{~min}$ to about $1 \mathrm{kN}$, significantly less than the initial green strength. In comparison, the briquette density increased slightly from 1.3 to $1.7 \mathrm{~g} / \mathrm{cm}^{3}$ as heating was increased from 3 to $5 \mathrm{~min}$. Further heating up to $15 \mathrm{~min}$ did not result in any further increase in briquette density. Figure 3 shows that the degree of iron metallization was about $45 \%$ after $3 \mathrm{~min}$ of heating and increased about $80 \%$ after $5 \mathrm{~min}$, but did not increase with further heating. An examination of the briquette microstructure after $10 \mathrm{~min}$ of heating (see Fig. 6) showed that no charcoal remained. It seems that the plateau in iron metallization may be due to insufficient charcoal in the briquette mix.

Figure 4 shows a micrograph of composite briquette particles from series 1 after $3 \mathrm{~min}$ of heating at $1300{ }^{\circ} \mathrm{C}$

Table 4 Experimental conditions used in the production of composite briquettes

\begin{tabular}{lllll}
\hline Series & Temperature $\left({ }^{\circ} \mathrm{C}\right)$ & Time at temperature (minutes) & C/Fe (wt ratio) & C/O (mole ratio) \\
\hline 1 & 1300 & $3,5,10$, and 15 & 0.24 & 0.74 \\
2 & 1300 & 10 & $0.18,0.20,0.22,0.24,0.26$ & $0.55,0.61,0.68,0.74,0.80$ \\
3 & 1300 & 15 & $0.18,0.20,0.22,0.24,0.26$ & $0.55,0.61,0.68,0.74,0.80$ \\
4 & 1350 & 10 & $0.18,0.20,0.22,0.24,0.26$ & $0.55,0.61,0.68,0.74,0.80$ \\
\hline
\end{tabular}




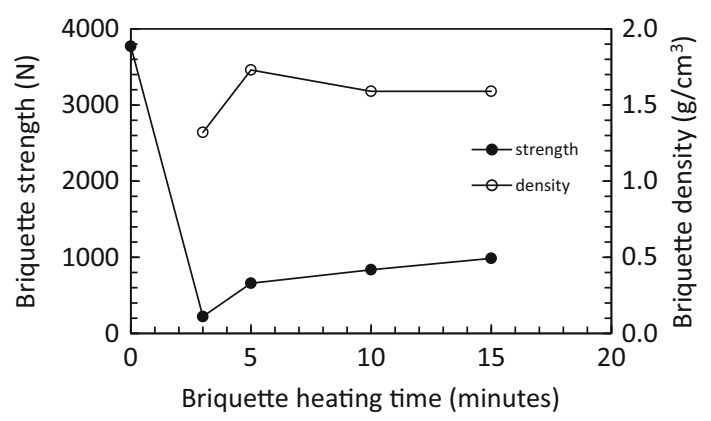

Fig. 2 The effect of time at temperature on briquette strength and density

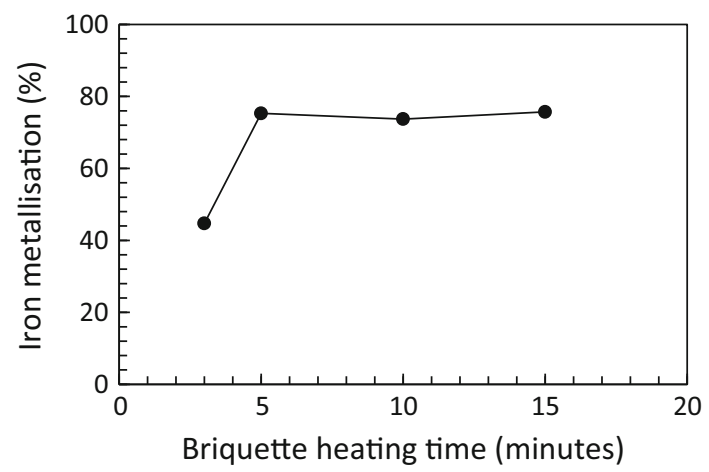

Fig. 3 The effect of time at temperature on iron metallization

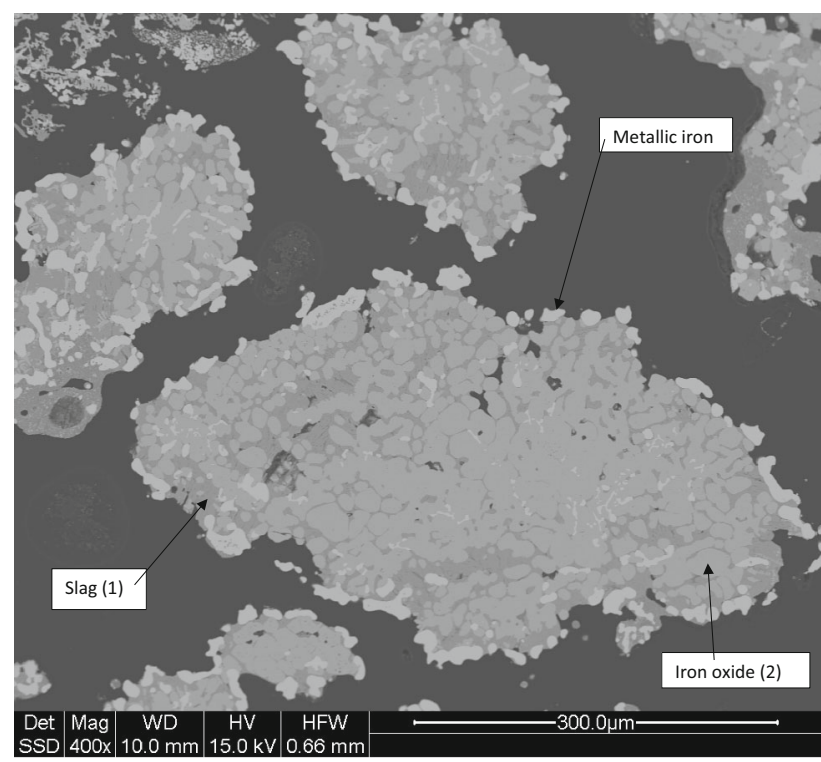

Fig. 4 SEM back-scatter image of a composite briquette from series 1 after heating for $3 \mathrm{~min}$ at $1300{ }^{\circ} \mathrm{C}$

$(\mathrm{C} / \mathrm{Fe}=0.24)$. The internal regions of the particles are composed mostly of $\mathrm{FeO}$ (labeled 2) grains with a small amount of interstitial slag (labeled 1). There is also a small amount of metallic iron along the outer edge of the particle (labeled 3). The reduction of the original hematite in the iron ore to wustite $(\mathrm{FeO})$ occurred quickly, (See Table 5). The initial $\mathrm{FeO}$ reduction could occur via the gasification of charcoal particles close to the edge of the composite particles due to faster heating. Subsequent reduction would occur in the bulk of the composite particle due to the gasification of interstitial carbon particles when the internal temperature reaches a critical temperature (see Figs. 5 and 6). The low compressive strength of these briquettes is likely due to void formation in the macrostructure and the relatively small amount of slag which is available to bind the particles.

Figure 5 shows a micrograph of a Series 1 briquette after $5 \mathrm{~min}$ heating at $1300{ }^{\circ} \mathrm{C}$. Unlike the microstructure after $3 \mathrm{~min}$, a continuous slag network is visible with relatively small amounts of iron oxide. The central dark feature is a void and not part of the microstructure. Large amounts of metallic iron are also dispersed in the slag network and are starting to coalesce. Dendritic iron oxide, present within the slag phase, is assumed to form during briquette cooling and is not thought to be part of the briquette structure at the experimental temperature. The progression and development of the slag phase shown in Figs. 4 and 5 are in consistent with the slag forming process described by Longbottom et al. [29] during the reduction of ironsand compacts.

Figure 6 shows a micrograph of a briquette after $10 \mathrm{~min}$ heating at $1300{ }^{\circ} \mathrm{C}$. In this case, the $\mathrm{FeO}$ domains have disappeared and the dominant phases are metallic iron and a continuous slag network. The metallic iron has continued to coalesce and has started to form continuous networks. No residual carbon is visible in this sample and its unavailability may have limited the metallization to $80 \%$ (Fig. 3).

The compositions of the slags in the briquettes heated for 3, 5, and $10 \mathrm{~min}$ are shown in Table 5. For all samples, the slag compositions are iron-rich and close to the fayalite composition $\left(\mathrm{Fe}_{2} \mathrm{SiO}_{4}\right)$, with small amounts of alumina and magnesia. This was fortuitous as the slag which naturally formed had a low melting temperature and additional fluxes were not necessary.

The slag from the briquette after 3 min heating is more enriched in iron than the other slag samples. This may decrease the melting temperature slightly. Slags close to the fayalite composition will have a melting temperature of close to $1200{ }^{\circ} \mathrm{C}$ and at the heating temperature of $1300{ }^{\circ} \mathrm{C}$, the slag would be expected to be fully molten and should readily fill the gaps between the $\mathrm{FeO}$ and iron particles. When cooled, this continuous slag structure would hold the briquette together and impart some strength. The low strength of the briquette after $3 \mathrm{~min}$ of heating can be attributed to the small amount of slag in this briquette. At longer heating times, more slag has been 
Table 5 Composition and identification of phases labeled in Figs. 4, 5, and 6

\begin{tabular}{|c|c|c|c|c|c|c|c|c|c|c|c|c|c|c|}
\hline \multirow[t]{2}{*}{ Heating time (min) } & \multirow[t]{2}{*}{ Label No. } & \multicolumn{6}{|c|}{ Normalized wt $\%$} & \multicolumn{6}{|c|}{ Normalized atomic $\%$} & \multirow[t]{2}{*}{ Phase } \\
\hline & & $\mathrm{Fe}$ & $\mathrm{Si}$ & $\mathrm{Al}$ & $\mathrm{Mg}$ & $\mathrm{Mn}$ & $\mathrm{O}$ & $\mathrm{Fe}$ & $\mathrm{Si}$ & $\mathrm{Al}$ & $\mathrm{Mg}$ & $\mathrm{Mn}$ & $\mathrm{O}$ & \\
\hline 3 & 1 & 54 & 12 & 1.4 & 1.3 & 0.7 & 29 & 29 & 13 & 1.5 & 1.6 & 0.4 & 54 & Slag \\
\hline 5 & 3 & 49 & 13 & 0.5 & 5 & 1.9 & 30 & 25 & 14 & 0.5 & 6.1 & 1.0 & 51 & Slag \\
\hline 10 & 5 & 50 & 14 & 0.5 & 4.2 & 1.7 & 30 & 25 & 14 & 0.5 & 4.9 & 0.9 & 54 & Slag \\
\hline 3 & 2 & 77 & 0 & 0.7 & 0.6 & 0 & 22 & 49 & 0 & 0.9 & 0.9 & 0 & 49 & $\mathrm{FeO}$ \\
\hline 5 & 4 & 77 & 0 & 0.3 & 0 & 0 & 22 & 49 & 0 & 0.4 & 0 & 0 & 49 & $\mathrm{FeO}$ \\
\hline
\end{tabular}

formed which would tend to increase briquette strength. Higher levels of iron metallization would reduce the iron content of the slag and could slightly increase the liquidus temperature. This may restrict the formation of a continuous slag phase. However with the range of $25-30 \% \mathrm{SiO}_{2}$ in the $\mathrm{SiO}_{2}-\mathrm{FeO}_{\mathrm{x}}-\mathrm{MgO}$ system, small changes in the silica content of slag have only a small effect on the liquidus temperature. At longer heating times, a continuous metallic network becomes prominent and this may also impart strength to the cooled briquette.

These results broadly agree with the work of Tsujihata [30], Gupta and Gautam [31], and Iguchi and Kamei [32]. Tsujihata attributed the mechanical strength of iron oxide agglomerates to the bonding between hematite crystals which are formed either by mutual diffusion or by slag generation. These bonds breakdown as the agglomerates are reduced. Tsujihata [30] showed that the crushing strength of an iron ore agglomerate decreased from $180 \mathrm{~kg}$ $(1764 \mathrm{~N})$ to about $30 \mathrm{~kg}(294 \mathrm{~N})$ as the degree of reduction increased from zero to $10 \%$. At high degrees of reduction, a metallic bond was found to impart strength on the agglomerate and pellet strength increased with the degree of reduction. For this reason, a high metallic iron content of pellets, greater than $70 \%$, is generally required in order for reduced pellets to attain the strength required for use in blast furnaces.

Gupta and Gautam [31] reasoned that the strength of DRI could be increased by enhanced metallic or slag bonding within the pellet. This could be achieved by higher reduction temperature and longer sintering time which would increase the fusion zone and increase the bond contact area. These comments agree with the work of Longbottom et al. [28, 29] on compacts made with iron sand and the present work where a slag network developed after a relatively short heating times of $5 \mathrm{~min}$.

Iguchi and Kamei [32] investigated the swelling behavior and crushing strength of individual composite pellets during reduction in oxygen-containing nitrogen atmospheres. As reduction continued, pellet strength decreased to a minimum after about 2 min. At longer reaction times the pellet strength increased. Ultimate pellet strength increased with increasing reduction temperature.
Fig. 6 SEM back-scatter image of a composite briquette from series 1 after heating for $10 \mathrm{~min}$ at $1300{ }^{\circ} \mathrm{C}$ 
The rise in pellet strength was accompanied with an increase in pellet density. This work agrees directly with the present work where reduced pellet strength also increased from a minimum at short heating times and increasing heating times, and temperature increased briquette strength through the development of a slag network.

\section{Effect of Carbon-to-Iron Ratio in Briquette}

Figure 7 shows that briquette strength increased with decreasing $\mathrm{C} / \mathrm{Fe}$ ratio. In general, stronger briquettes were produced by heating at $1300{ }^{\circ} \mathrm{C}$ for $15 \mathrm{~min}$ and the weakest by heating at $1300{ }^{\circ} \mathrm{C}$ for $10 \mathrm{~min}$. At the highest $\mathrm{C} / \mathrm{Fe}$ ratio of 0.26 , all three conditions produced heated briquettes of about the same strength $(700-950 \mathrm{~N})$. At the lowest $\mathrm{C} / \mathrm{Fe}$ ratio, briquettes from the second series $\left(1300{ }^{\circ} \mathrm{C}\right.$ for $\left.15 \mathrm{~min}\right)$ produced the strongest briquettes $(5000 \mathrm{~N})$.

The trends in Fig. 7 are consistent with the conclusions of Longbottom et al. [29] who reasoned that strong reduced compacts of coal and ironsand form when the original iron oxide particles are close together. An incipient slag phase forms between the particles and grows to envelope them. Iron oxide particles that are close together facilitate the connection of the slag phase and result in a stronger more consolidated structure. Low $\mathrm{C} / \mathrm{Fe}$ ratios in the briquettes of this work would also decrease the distance between oxide particles and hence will result in an increase in briquette strength after heating. Factors which were investigated, including higher temperature and longer heating time, would facilitate the formation of the slag phase and hence increase briquette strength.

Figure 8 shows that briquette density after heating decreases with increasing $\mathrm{C} / \mathrm{Fe}$ ratio. In general, denser briquettes were obtained by increasing the heating temperature from 1300 to $1350{ }^{\circ} \mathrm{C}$ and by increasing the heating time from 10 to $15 \mathrm{~min}$. At high $\mathrm{C} / \mathrm{Fe}$ ratios, there was little difference between the three sets of results. However, at the lowest $\mathrm{C} / \mathrm{Fe}$ ratio, the briquette from the second test series $\left(1300{ }^{\circ} \mathrm{C}\right.$ and $\left.15 \mathrm{~min}\right)$ produced a density

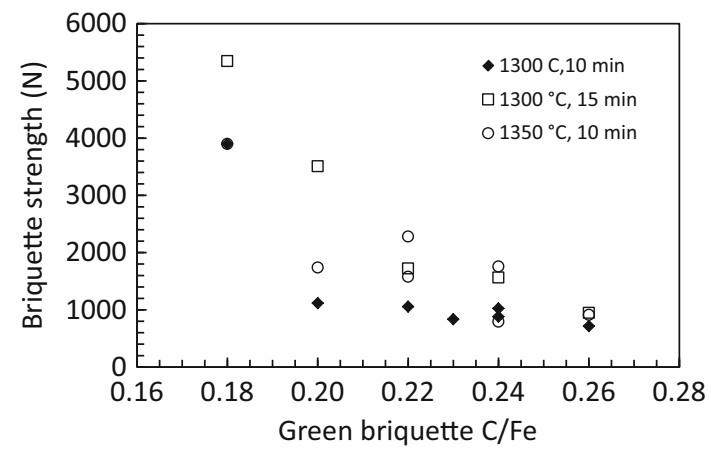

Fig. 7 The effect of briquette strength plotted against $\mathrm{C} / \mathrm{Fe}$ ratio

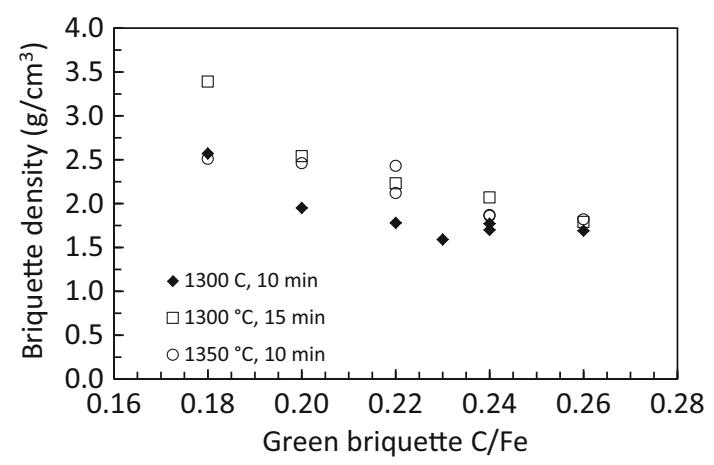

Fig. 8 The effect of briquette density plotted against $\mathrm{C} / \mathrm{Fe}$ ratio

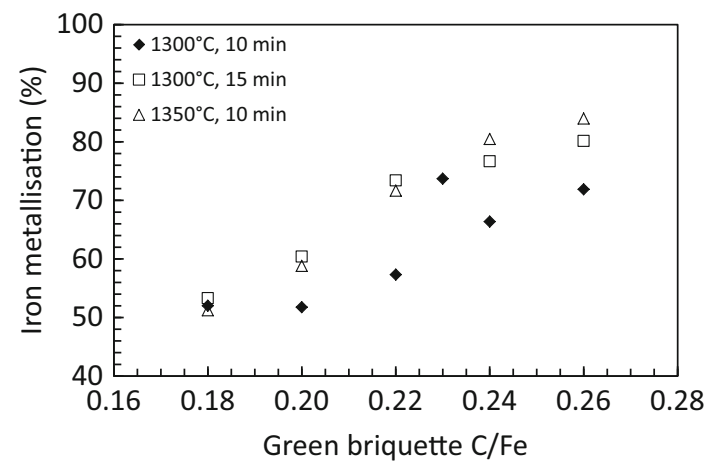

Fig. 9 The effect of briquette iron metallization plotted against $\mathrm{C} / \mathrm{Fe}$ ratio

after heating of about $3.5 \mathrm{~g} / \mathrm{cm}^{3}$, compared to about $2.5 \mathrm{~g} /$ $\mathrm{cm}^{3}$ for the other two test series, but this may be within experimental error due to difficulties in measuring the dimensions of the reduced briquettes.

Figure 9 shows that the degree of iron metallization in the heated briquettes increased with increasing $\mathrm{C} / \mathrm{Fe}$ ratio. The results from series $2\left(1300{ }^{\circ} \mathrm{C}, 10 \mathrm{~min}\right)$ show lower levels of iron metallization compared to the briquettes heated to a higher temperature and held in the furnace for longer. Briquettes from series $3\left(1300{ }^{\circ} \mathrm{C}\right.$ and $\left.15 \mathrm{~min}\right)$ showed slightly higher levels of iron metallization at low $\mathrm{C} / \mathrm{Fe}$ ratios compared to briquettes from series $4\left(1350{ }^{\circ} \mathrm{C}\right.$, $10 \mathrm{~min}$ ). At higher $\mathrm{C} / \mathrm{Fe}$ ratios, the briquettes from series 4 $\left(1350{ }^{\circ} \mathrm{C}, 10 \mathrm{~min}\right)$ had slightly higher level of iron metallization at about $80 \%$. Iron ore particles are reduced by $\mathrm{CO}$ gas which forms from the gasification of charcoal with $\mathrm{CO}_{2}$ gas according to Eq. (1). In briquettes with relatively large amounts of charcoal, iron oxide reduction via Eq. (6) is likely to occur to a greater extent. This will increase the yield of metallic iron per unit of carbon reacted due to increased $\mathrm{CO}$ formation.

Other researchers obtained higher levels of iron metallization in the reduction of iron/carbon compacts than what was obtained in this work through the use of higher $\mathrm{C} / \mathrm{Fe}$ 


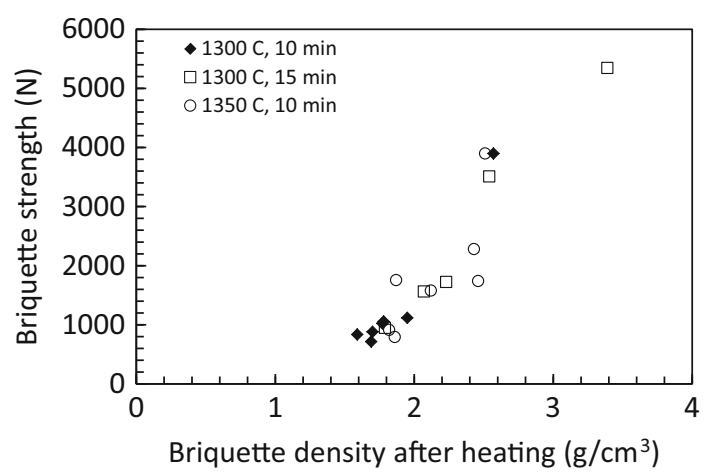

Fig. 10 The effect of briquette strength with density

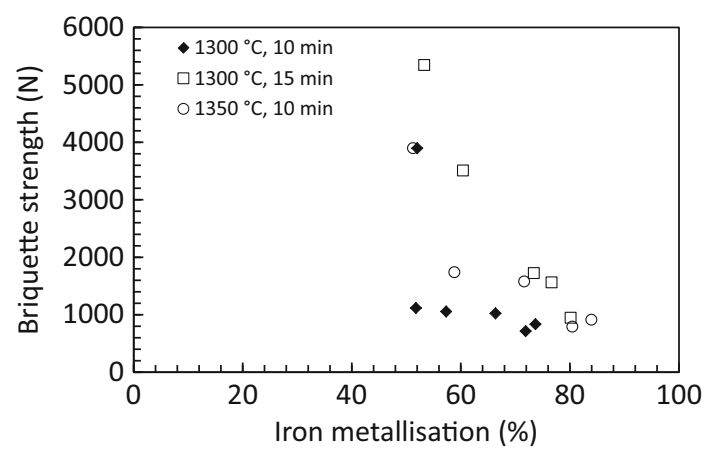

Fig. 11 The effect of briquette strength with iron metallization

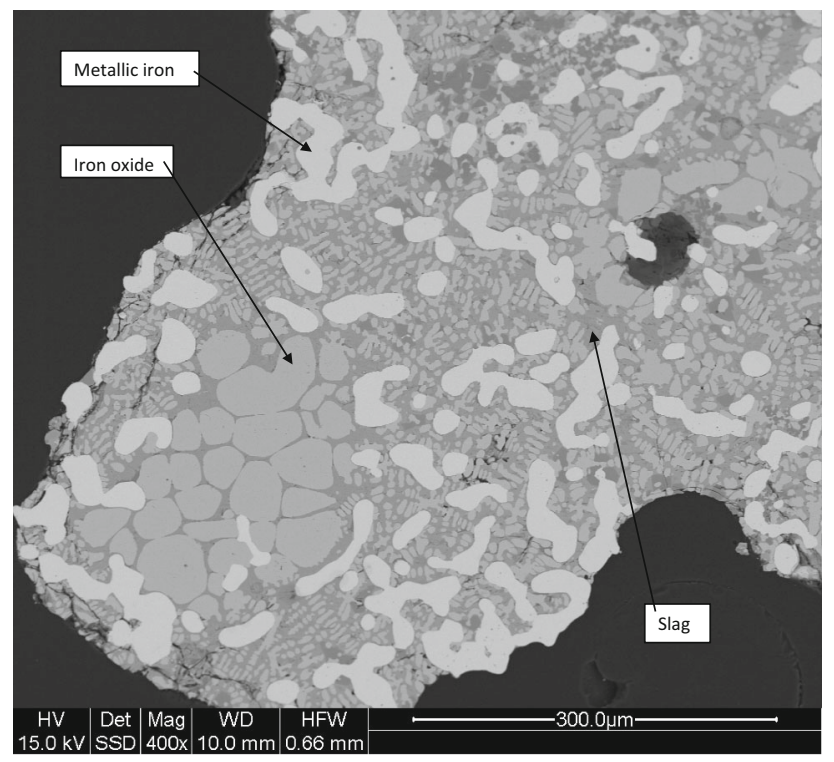

Fig. 12 SEM back-scatter image a briquette with $\mathrm{C} / \mathrm{Fe}$ ratio of 0.18 after heating at $1300{ }^{\circ} \mathrm{C}$ for $15 \mathrm{~min}$

ratios, longer heating times or higher temperatures [10, 29, 33-36]. The present work did not cover composite briquettes made with charcoal at higher $\mathrm{C} / \mathrm{Fe}$ ratios than 0.26

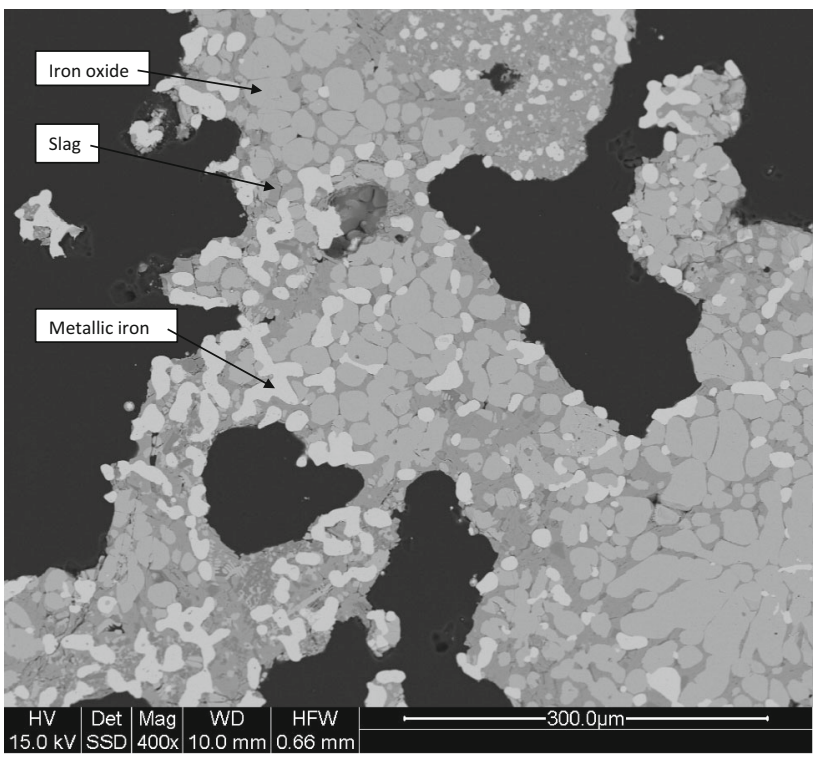

Fig. 13 SEM back-scatter image of a briquette with $\mathrm{C} / \mathrm{Fe}$ ratio of 0.22 after heating at $1300{ }^{\circ} \mathrm{C}$ for $15 \mathrm{~min}$

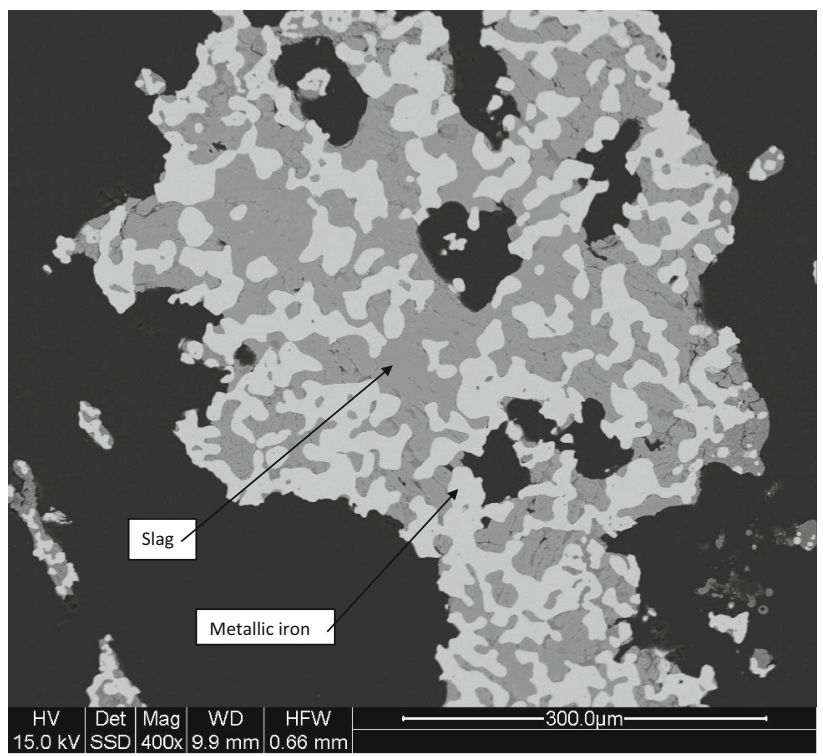

Fig. 14 SEM back-scatter image of a briquette with $\mathrm{C} / \mathrm{Fe}$ ratio of 0.26 after heating at $1300{ }^{\circ} \mathrm{C}$ for $15 \mathrm{~min}$

as the focus was on the strength of heated briquettes. However, investigations into the strength and iron metallization of charcoal/iron ore briquettes made at high $\mathrm{C} / \mathrm{Fe}$ ratios would make a worthwhile area for future work.

The results shown in Figs. 7, 8, and 9 indicate that briquette strength should show a positive trend with briquette density after heating. The relationship is illustrated in Fig. 10 which indicates that the briquette strength has a high dependence on briquette density. Figure 11 shows the variation of briquette strength with the degree of iron 
Table 6 Calculation of slag weight and proportion of slag in heated briquettes

\begin{tabular}{|c|c|c|c|c|c|c|c|}
\hline $\begin{array}{l}\mathrm{C} / \\
\mathrm{Fe}\end{array}$ & $\begin{array}{l}\text { Temperature } \\
\left({ }^{\circ} \mathrm{C}\right)\end{array}$ & $\begin{array}{l}\text { Heating } \\
\text { time (min) }\end{array}$ & $\begin{array}{l}\text { Total } \mathrm{SiO}_{2} \text { in } \\
\text { briquette }(\mathrm{g})\end{array}$ & $\begin{array}{l}\mathrm{SiO}_{2} \text { in slag } \\
\text { phase }(\%)\end{array}$ & $\begin{array}{l}\text { Amount of slag in } \\
\text { briquette }(\mathrm{g})\end{array}$ & $\begin{array}{l}\text { Mass of heated } \\
\text { briquette }(\mathrm{g})\end{array}$ & $\begin{array}{l}\text { Proportion of slag in } \\
\text { heated briquette }(\%)\end{array}$ \\
\hline 0.18 & 1300 & 10 & 0.90 & 25.5 & 3.53 & 16.85 & 20.9 \\
\hline 0.22 & 1300 & 10 & 0.88 & 25.7 & 3.43 & 16.62 & 20.7 \\
\hline 0.26 & 1300 & 10 & 0.87 & 26.4 & 3.27 & 16.00 & 20.5 \\
\hline 0.18 & 1300 & 15 & 0.90 & 21.1 & 4.24 & 16.57 & 25.6 \\
\hline 0.22 & 1300 & 15 & 0.89 & 26.0 & 3.41 & 15.90 & 21.4 \\
\hline 0.26 & 1300 & 15 & 0.86 & 22.2 & 3.87 & 15.05 & 25.7 \\
\hline 0.18 & 1350 & 10 & 0.91 & 25.0 & 3.63 & 17.02 & 21.4 \\
\hline 0.22 & 1350 & 10 & 0.90 & 25.9 & 3.47 & 16.28 & 21.3 \\
\hline 0.26 & 1350 & 10 & 0.87 & 22.6 & 3.85 & 15.15 & 25.4 \\
\hline
\end{tabular}

metallization. High-strength briquettes are associated with relatively low levels of iron metallization (about $50 \%$ ). At iron metallization levels greater than about $60 \%$ the data become scattered. For the conditions of series $3\left(1300{ }^{\circ} \mathrm{C}\right.$ for $15 \mathrm{~min})$ and to a lesser extent series $4\left(1350{ }^{\circ} \mathrm{C}\right.$ for $10 \mathrm{~min}$ ), the relationship shows that the conditions that produce higher strength briquettes result in lower levels of iron metallization, presumably due to the slag formation mechanisms previously discussed.

Carbon is consumed during reduction, tending to increase porosity and lower briquette density as metallization increases. However, it is observed that contraction in overall dimensions also takes place. Overall, it seems that as iron metallization increases the internal structures of the briquette contract leaving higher porosity (more voids) and a lower density. This increased porosity weakens the briquette structure and reduces its compressive strength.

This progression can be illustrated in the microstructure of heated briquettes from the third series $\left(1300{ }^{\circ} \mathrm{C}\right.$ and $15 \mathrm{~min}$ of heating). Figures 12, 13, and 14 show the microstructure of the briquette with $\mathrm{C} / \mathrm{Fe}$ ratios of 0.18 , 0.22 , and 0.26 , respectively.

In Fig. 12, the dominant phases are metallic iron, iron oxide, and a continuous slag phase. Reduction is incomplete in this sub-stoichiometric $\mathrm{C} / \mathrm{Fe}$ case. The smaller dendritic iron oxide phases are likely to have precipitated from the slag after the briquette cooled. Figure 13 shows a less consolidated structure but still with plenty of iron oxide, i.e., incomplete reduction. The slag phase is continuous and surrounds the iron oxide particles. The iron has started to coalesce. In Fig. 14, the iron oxide phase is no longer, and the remaining phases are metallic iron and the continuous slag. The metallic iron has coalesced to a large extent and has started to form longer range networks. Metallization was $80 \%$, with a significant amount of iron remaining in the slag.

Although the microstructures in Figs. 12, 13, and 14 represent a small fraction of the surface area of each

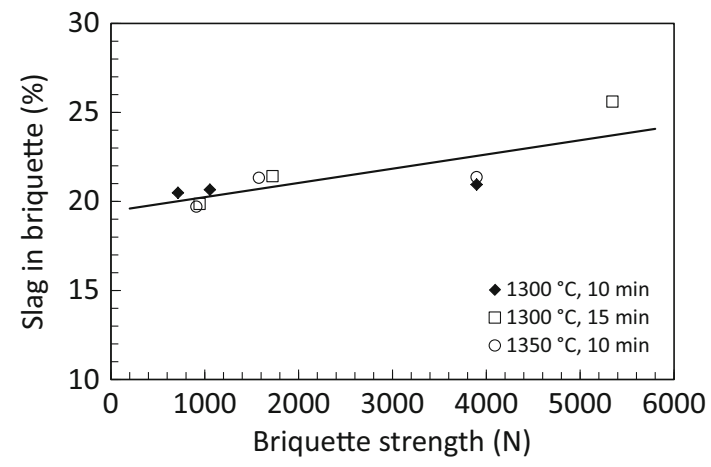

Fig. 15 Graph of the proportion of slag in the briquette plotted against the briquette strength

briquette, they are the representatives of the briquette as a whole. In Fig. 12, the microstructure is consolidated with few pores. In Fig. 13, the briquette structure is less massive with large pores. In Fig. 14, the microstructure contains smaller and narrower solid briquette pieces which lack the cohesiveness of the microstructure of Fig. 12 or even Fig. 13. This change in microstructure is consistent with a decrease in briquette strength.

It is possible to calculate the proportion of slag in the briquette structure by noting that silica reports only to the slag phase. Hence, the amount of slag as a proportion of the total briquette mass can be calculated from the amount of silica in the original briquette mix (from iron ore and charcoal ash), and the silica content of the slag phase determined by EDS analysis. This information is shown in Table 6 for some selected samples. Figure 15 shows the calculated proportion of slag in the briquette as a function of briquette strength. The slight positive slope indicates that briquette strength increases with the amount of slag formed. It is reasonable to conclude that this slag provides a bonding phase which bounds the briquette together and provides the briquette with compressive strength. 


\section{Conclusions}

The dried green briquettes had high compressive strength and required a force of at least $3500 \mathrm{~N}$ to yield. This strength rapidly decreased during heating at $1300{ }^{\circ} \mathrm{C}$ to $200 \mathrm{~N}$ before steadily increasing to $1000 \mathrm{~N}$ at heating times of $15 \mathrm{~min}$. The density and degree of iron metallization of the briquettes remained constant after $5 \mathrm{~min}$ of heating. The increase in briquette heating was attributed to the development of a slag phase which binds the metallic and remaining iron oxide particles together into a coherent solid mass.

Increasing the $\mathrm{C} / \mathrm{Fe}$ ratio in the briquette mix decreased the strength and density and increased the degree of iron metallization of the heated briquettes. Briquette strength also increased with increasing time from 10 to $15 \mathrm{~min}$ and heating temperature from 1300 to $1350{ }^{\circ} \mathrm{C}$. These observations can be explained by the distance between iron oxide particles in the briquette mix. At low $\mathrm{C} / \mathrm{Fe}$ ratios, iron oxide particles will be relatively close together. This closeness facilitates the development of a slag phase and hence increases briquette strength. The closeness of the iron particles also increases the briquette density. The higher amounts of carbon in the briquettes made at high $\mathrm{C} / \mathrm{Fe}$ ratio results in higher levels of $\mathrm{CO}$ gas generation and hence higher levels of iron oxide reduction resulting in higher levels of iron metallization. Briquette strength was found to correlate positively with briquette density and inversely with iron metallization.

The compressive strength of heated briquettes correlated positively with the proportion of slag in the briquette. This observation supports the conclusion that slag plays an important role in providing strength to heated composite briquettes.

Overall, low VM charcoal was found to be a very satisfactory reductant for use in carbon-hematite composite briquettes, and conditions for the production of highstrength, high-metallization DRI have been determined.

Acknowledgments This work was performed as part of the Australian $\mathrm{CO}_{2}$ breakthrough research program which was a collaboration between Arrium, BlueScope Steel, and CSIRO Mineral Resources. The financial and technical assistance of Arrium and BlueScope Steel in the conduct of the work is gratefully acknowledged. The author is also grateful for the assistance of Dr Matthew Glenn and Mr Rowan Davidson of CSIRO Mineral Resources who performed the SEM investigations and performed the experimental work respectively for this paper.

\section{References}

1. Chatterjee A (1994) Beyond the blast furnace. CRC Press, Boca Raton

2. Hoffman GE (2000) A closer look at Fastmet and Fastmelt. In: Proceedings of 2000 electric Furnace Conference, AIST, Warrendale, $\mathrm{PA}$
3. Jimbo J, Miyagawa Y, Fujitomi M, Kobayashi I, Matsumura T, Nishimura M (1997) Development of FASTMET process as an iron unit, Kobelco technology review, No. 20, pp 6-10

4. Nogami T (2001) ITmk3: premium iron making process for the new millennium, Direct from Midrex, 1st Quarter 2001, p 7-9

5. Machado JGMS, Osovio E, Vilela ACF, Babich A, Senk D, Gudenan HW (2010) Reactivity and conversion of Brazilian and imported coals, charcoals and blends in view of their injection into blast furnaces. Steel Res Int 81(1):9-16

6. Jahanshahi S, Mathieson JG, Somerville MA, Haque N, Norgate TE, Deev A, Pan Y, Xie D (2015) Development of low emission integrated steelmaking process. J Sustain Metall 1:94-114

7. Mathieson JG, Somerville MA, Deev A, Jahanshahi S (2015) Utilization of biomass as an alternative fuel in ironmaking. In: Lu L (ed) Iron Ore. Elsevier, Amsterdam, pp 581-613

8. Ghosh A (1999) Kinetics and mechanisms of reduction in composite iron ore-reductant pellets. In: Misra VN, Holmes RJ (eds) Proceedings of international conference on alternative routes of iron and steelmaking, Perth WA, AusIMM, Melbourne, 15-17 Sept 1999, pp 71-78

9. Seaton CE, Foster JS, Velasco J (1983) Reduction kinetics of hematite and magnetite pellets containing coal char. Trans ISIJ 23:490-496

10. Donskoi E, Olivares RI, McElwain DLS, Wibberley LJ (2006) Experimental study of coal based direct reduction in iron ore/coal composite pellets in a one layer bed under non isothermal, asymmetric heating. Ironmak Steelmak 33(1):24-28

11. Wang Q, Yang Z, Tian J, Sun J (1998) Reduction kinetics of iron ore-coal pellet during fast heating. Ironmak Steelmak 25(6):443-447

12. Huang B-H, Lu W-K (1993) Kinetics and mechanisms of reactions in iron ore/coal composites. ISIJ Int 33(10):1055-1061

13. Sharma T (1997) Reduction of double layered iron ore pellets. Int J Miner Process 49:201-206

14. Pandey BK, Sharma T (2000) Reducing agents and double-layered iron ore pellets. Int J Miner Process 59:295-304

15. Dutta SK, Sah R (2009) Smelting reduction of composite pellets as alternative ironmaking. In: Proceedings of 5th international congress on the science and technology of ironmaking, The Chinese Society of Metals, Shanghai 20-23 Oct 2009

16. Fortini OM, Fruehan RJ (2005) Rate of reduction of ore-carbon composites: part 1 determination of intrinsic rate constants. Metall Mater Trans B 36:865-872

17. Halder S, Fruehan RJ (2008) Reduction of iron oxide-carbon composites: part 1, estimation of rate constants. Metall Mater Trans B 39:784-795

18. Gupta RC, Misra SN (2001) Composite pre-reduced pellet quality as affected by reductant reactivity. ISIJ Int 41:S9-S12

19. Dutta SK, Ghosh A (1995) Evaluation of various cold bonding techniques for iron ore-coal/char composite pellets. Trans Indian Inst Metall 48:1-13

20. Agrawal BB, Chauhan GIS (2006) Development of ore-coal composite pellets for sponge iron making. In: EPD Congress 2006, The Minerals, Metals \& Materials Society, Warrendale, PA, p 241-246

21. Agrawal BB, Prasad KK, Sarkar SB, Ray HS (2000) Cold bonded ore-coal composite pellets for sponge iron making. Part 1 laboratory scale development. Ironmak Steelmak 26(6):421-426

22. Shivaramakrishna N, Agrawal BB, Ray AK, Prasad KK, Bandopadhyay PK, Gupta SK (1990) Production of high carbon sponge iron from ore-coal composite pellets. Trans Indian Inst Metall 43(2):95-101

23. Ganguly A, Patalah AA (1990) Sponge iron fines as a binder in ore-coal composite pellets. Trans Indian Inst Metall 43(5):288-293 
24. Mantovani MC, Takano C, Buchler PM (2002) Electric arc furnace dust-coal composite pellet: effects of pellet size, dust composition and additives on swelling and zinc removal. Ironmak Steelmak 29(4):257-265

25. Takahashi R, Akiyama T, Yagi J-I (1990) Drying and reduction of cement bonded pellets using a moving bed reactor. In: Proceedings of sixth international iron and steel conference, Nagoya, ISIJ, pp 108-115

26. Aota J, Morin L, Zhuang Q, Clements B (2006) Direct reduced iron production using cold bonded carbon bearing pellets part 1laboratory metallisation. Ironmak Steelmak 33(5):426-428

27. Zhuang Q, Clements B, Aota J, Morin L (2006) Direct reduced iron production using cold bonded carbon bearing pellets. Part 1rotary kiln process modelling. Ironmak Steelmak 33(5):429-432

28. Longbottom RJ, Monaghan BJ, Nightingale SA, Mathieson JG (2013) Strength and bonding in reduced ironsand-coal compacts. Ironmak Steelmak 40(5):381-389

29. Longbottom RJ, Monaghan BJ, Mathieson JG (2013) Development of a bonding phase within titanomagnetite-coal compacts. ISIJ Int 53(7):1152-1160

30. Tsujihata K, Mitoma I, Fukagawa $\mathrm{Y}$, Hashimoto S, Toda $\mathrm{H}$ (1970) Pre-reduced material in blast furnace charge. Trans ISIJ 10:38-46
31. Gupta RC, Gautam JP (2003) The effect of additives and reductants on the strength of reduced iron ore pellet. ISIJ Int 43(12):1913-1918

32. Iguchi Y, Kamei R (1999) Formation of partially reduced iron by heating iron ore-coal char composite pellet in oxygen bearing gas flow: reactions, swelling rate and crushing strength. Tetsu Hagane 85(6): $13-20$

33. Wang G, Xue QG, Zhao YX, Wang JS (2014) Strength and high temperature behaviour of carbon composite pellets containing BOG fine dust. Ironmak Steelmak 41(8):591-597

34. Cevik E, Ahatci H, Sun Y (2013) Characterization and reduction behaviour of cold bonded composite pellets for direct reduction using an organic binder. Metallurgist 57(5-6):468-477

35. Lee YS, Ri DW, Yi SH, Sohn I (2012) Relationship between the reduction degree and strength of DRI pellets produced from iron and carbon bearing wastes using an RHF simulator. ISIJ Int 52(8):1454-1462

36. Park H, Sahajwalla V (2014) Reduction behaviour of carbon composite pellets including alumina and silica at $1273 \mathrm{k}$ and 1373 K. ISIJ Int 54(6):1256-1265 